\title{
ON THE FORMATION OF VERB COMPOUNDS IN EARLY MIDDLE JAPANESE
}

\author{
LI Wenchao \\ Zhejiang University, China \\ wideliau@gmail.com
}

\begin{abstract}
This paper is dedicated to the formation of verb compounds in Early Middle Japanese, a stage of the Japanese language used in the Heian Period (794-1185). The findings reveal that current verb compounds have come a long way from Old Japanese. Multiple verbs in Old Japanese are assigned to an associate type, rather than a compounding type of relation. Thus, the serial constituents receive equal syntactic weight, giving rise to the extensive use of the coordinate type and succession type of multi-verbs. In Early Middle Japanese, the combinations of the two constituents seem much tighter, giving rise the frequent use of the modifier-predicate $\mathrm{V}-\mathrm{V}$. The conclusion emerging from this study is that it was not until Early Middle Japanese that verb compounds in the strict sense appeared. Moreover, two types of verb weakening are observed in Early Middle Japanese: (a) transformation of the first verb into a prefix, (b) grammaticalization of the second verb into a directional/resultative complement.
\end{abstract}

Keywords: Old Japanese; Early Middle Japanese; verb compounds; argument structure; grammaticalization

\section{Izvleček}

Članek se posveča formaciji sestavljenih glagolov v zgodnje-srednji japonščini (obdobje Heian, 794-1185). Rezultati raziskave kažejo, da so današnje oblike sestavljenih glagolov precej drugačne od tistih v stari japonščini. V večbesednih glagolih v stari japonščini so bili odnosi med posameznimi deli na ravni navezovanja, medtem ko današnji pripisani povezovanju. $\mathrm{V}$ stari japonščini je imel vsak posamičen del sestavljenega glagola dodeljeno enakovredno sintaktično vlogo, kar je privedlo do razširjene uporabe priredno sestavljenih in zaporedno sestavljenih večbesednih glagolov. V zgodnje-srednji japonščini je vez med členi takšnega glagola postala tesnejša, kar je spodbudilo odnos določilo-povedkovnik. Iz tega lahko zaključimo, da sestavljeni glagoli izvirajo iz zgodnje-srednje japonščine. Poleg tega smo ugotovili, da sta v zgodnje-srednji japonščini obstajala dva tipa glagoskega šibljenja, to sta a) dodajanje predpon glagolom in (b) gramatikalizacija glagolov, pri kateri nastanejo smernorezultatska dopolnila.

Ključne besede: stara japonščina; zgodnje-srednja japonščina; sestavljeni glagoli; struktura argumenta; gramatikalizacija

This work was supported by the Fundamental Research Funds for the Central Universities.

Acta Linguistica Asiatica, 3(2), 2013. ISSN: 2232-3317, http://revije.ff.uni-lj.si/ala/

DOI: $10.4312 / a l a .3 \cdot 2.25-40$ 


\section{Introduction}

Early Middle Japanese is a stage of the Japanese language that was used in the Heian Period (794-1185). Compared with Old Japanese, there is a range of phonological changes. Firstly, the sound characteristics, reflected in Jödai Tokushu Kanazukai are completely lost. From the $10^{\text {th }}$ to the $11^{\text {th }}$ century, /e/ and /je/ merge into /e/; /o/ and /wo/ merge into /o/. Second, prenasalised consonants shift to voiced consonants. The change further accompanies the development of the writing system. Early Middle Japanese shifted from man'yogana to the purely phonetic script hiragana. Three forms of writing existed: (a) a mixture of hentaikanbun and man'yōgana, mostly used in documentary; (b) hiragana kanji majiri bun, "a mixture of Chinese characters and Japanese hiragana syllabary characters", mostly used in poems or tales; (c) kanji katakana majiri bun, "a mixture of Chinese characters and katakana syllabary characters", extensively used in the Late Heian Period.

This brings us to the issue of whether verb compounding might differ accompanying the shift of writing systems in Early Middle Japanese. This paper takes the multi-verbs ${ }^{1}$ in Old Japanese as a point of departure and moves towards a more unified account of how verb compounds are built in Early Middle Japanese. The paper is organized as follows.

Section 2 gives a brief introduction to the formation of multi-verbs in Old Japanese; this serves as the starting point of this study.

Section 3 moves on to the formation of verb compounds in Early Middle Japanese, focusing upon the argument structure.

Section 4 searches for the shifts that lie in the morphology and lexicon in the different stages, in order to ascertain trends in the development of $\mathrm{V}-\mathrm{V}$ formation from Old Japanese to Early Middle Japanese.

Section 5 highlights the distinct formation conditions of $\mathrm{V}-\mathrm{V}$ compounds and concludes the paper.

The data for this paper come from: (a) Monogatari literature, including Eiga Monogatari (EGM), Genji Monogatari (GJM), Heike Monogatari (HKM), Ise Monogatari (ISM) and Ujijui Monogatari (UJM); (b) Nikki diaries, including Tosanikki (TSK), Makura no Sōshi (MKS); (c) Waka poetry, including Kokin Wakashū (KKW); (d) Setsuwa literature, including Konjaku Monogatarishū (KJM).

\footnotetext{
${ }^{1}$ To make a distinction with V-V combinations in Early Middle Japanese, this paper refers to serial verb constructions of Old Japanese as multi-verbs. Moreover, this paper only deals with two-verb constructions. Three-verb constructions are not tackled.
} 


\section{Multi-verbs in Old Japanese}

Before attempting to see how the verb compound in Early Middle Japanese is built, it seems appropriate to sketch an overview of multi-verb constructions in Old Japanese.

\subsection{An introduction to Old Japanese}

The Japanese language employed Chinese characters to represent vernacular Japanese on paper before the development of the purely phonetic hiragana script (in the late 800s AD). Kojiki, the oldest extant chronicle in Japan, is written in a mixed Chinese-Japanese script, which is termed hentai-kanbun "variant Chinese". Variant Chinese refers to a script that is a combination of Chinese and a phonetic transcription of Japanese. Nihon shoki is the second oldest extant chronicle and was written in classical Chinese. Man'yōshü is the oldest collection of Japanese poetry and was written in man'yōgana, with Chinese characters used roughly in three principal ways, i.e., to represent Japanese words, to represent Japanese syllables, and to write Chinese loanwords.

\subsection{Variation of multi-verbs in Old Japanese}

Given this background and on the basis of Li's (2012) insights, perhaps we can give a rough description of multi-verbs $(\mathrm{M}-\mathrm{V})$ in Old Japanese as:

a. Coordinate $\mathrm{M}-\mathrm{V}$, i.e. (1)-(2)

b. Successive M-V, i.e. (3)-(4)

c. Modifier-predicate M-V (V1 modifiers V2), i.e. (5)-(6)

d. Predicate-modifier M-V (V2 modifiers V1), i.e. (7)-(8)

e. Predicate-complement M-V, i.e. (9)-(10)

\section{Coordinate M-V:}

(1) 石橋 ipapasi ni stepping-stone

生 靡 留 opwi-nabik-yeru

玉藻

tamamo

毛 叙 ${ }^{2}$ "The water-weeds grow along the stepping stone in a fluttering way." (MYS.2.196)

\footnotetext{
${ }^{2}$ The analysis and glossing of Old Japanese examples follow Frellesvig (2010). A list of abbreviations is given at the end of the paper.
} 
（2）足受利四管 頓情失奴 asi-zuri situtu tatimatini kokoro ke-use- nu feet scoot-INF. CONT quickly.ADV heart vanish-get lost PERF "Keep scooting over, then, the heart does not vanish nor get lost" (MYS.9.1740)

\section{Successive M-V:}

（3）佐韋 賀波 用 久毛多知 知多理

sawi gapa ywo kumwo tatiwatari Sai river ITJ cloud rise- cross.INF "Marry the older, and the first person who reaches the top of the mountain." (KK. 20)

(4) 物乃布 能八十氏 河 尔 玉藻成 ${ }^{3}$ 浮倍 流 礼 mononopu no ya- swoudi gapa ni tamamonasu ukabe-nagas-ere Samurai GEN many clan river DAT seaweed float-flow.PASS "Many people throng into the river to work like seaweed." (MYS.1.50)

In (3) and (4), V1 and V2 are interpreted to be in successive relation. In other words, the $\mathrm{V}-\mathrm{V}$ combination is considered to be equivalent to Modern Japanese "participle complex predicate (V-te-V)".

\section{Modifier-predicate M-V:}

(5) 青 香具山 者 日經 乃 大 御 門 尔

awo kagu yama pa pi notate no opo-mi kadwo ni

green Kagu hill TOP eastern GEN HON gate DAT

春山跡之美佐備 立 有

paru yama tosi mi sabwi- tat-eri

spring-time hill PART HON towerin- stand.NMNL

"The green hill of Kagu of Yamato stands at the eastern gate, a luxuriant spring-time hill."

(MYS.1.52)

（6）十六社者伊波比拝目 鶉 已曽伊波比廻礼 sisi koso ba ipapi-worogame udura koso ipapi-motopore pig deer FOC COND creep-worship quail FOC creep-worship "Pigs, deer and quails creep to worship."

(MYS.3.239)

3 玉藻成: 枕詞 for 浮倍流礼 


\section{Predicate-modifier M-V:}

$\begin{array}{llllll}\text { (7) 引馬 } & \text { 野 } & \text { 尔 } & \text { 仁保布 } & \text { 榛原 } & \text { 入乱 } \\ \text { pikuman } & \text { wo } & \text { ni } & \text { nipopu } & \text { paripara } & \text { iri-midare }\end{array}$

Hikuma Plain DAT beautiful bush-clover push through-freely

"Pushing freely through the bush-clovers, flowering on Hikuma plain."

(MYS.1.57)

（8） 玉桙 ${ }^{4}$ 乃道 行晚

tamapoko no miti yuki-kurasi

Tamahoko COP road go-benighted.INF

"I walk on the way until it gets dark."

(MYS.1.79)

\section{Predicate-complement M-V:}

（9）婇女 乃袖

une mye no swode puki-kapyesu asuka kaze

lady GEN sleeve blow-flutter.CONCL Asuka wind "The gentle winds at Asuka fluttered the ladies' sleeves."

(MYS.1.51)

(10) 秋 立 者黄葉

aki tate ba momiti

頭刺 理 逝 副

fall come. COND tinted leaves plug.INF guki-sopu

"When autumn comes, the leaves tint (the god of mountains) godly tributes to the throne."

(MYS.1.38a)

To sum up briefly, multi-verbs in Old Japanese contain three variations in argument structure, as shown in Table 1.

Table 1: Variation of argument structure of multi verbs in Old Japanese

(The examples are drawn from MYS)

\begin{tabular}{|l|l||}
\hline \hline Argument structure & Example \\
\hline $\begin{array}{l}\text { 1. intransitive V+ } \\
\text { intransitive V }\end{array}$ & $\begin{array}{l}\text { 出で行く, 出で来, 鳴き渡る, なづみ来, 濡れ通る, 乱れ出づ } \\
\text { 越え去め, 越え行く, 越え来, 咲き散る, 立ち往ぬ }\end{array}$ \\
\hline $\begin{array}{l}\text { 2. transitive V+ } \\
\text { unaccusative V }\end{array}$ & 負ひ来, 恋ひ行く, 恋ひ来, 恋ひ渡る, 持ち行く \\
\hline $\begin{array}{l}\text { 3. intransitive V+ } \\
\text { transitive V }\end{array}$ & 出で見る、帰り見る \\
\hline
\end{tabular}

4 玉桙: 枕詞 for 道 road 
With this in place, perhaps we can pause and draw a preliminary conclusion here: morphosyntax played a central role in Old Japanese. Crucially, the combination of the two constituents appears relatively loose. The two constituents in other words seem to receive equal weight syntactically and morphologically.

\section{Verb compounds ${ }^{5}(\mathrm{~V}-\mathrm{V})$ in Early Middle Japanese}

We are now in the position to consider the formation of verb compounds in Early Middle Japanese by focusing upon the argument structure. Based on our data, it appears that at least four variations are available for building a verb compound, namely, (a) modifier-predicate type, (b) coordinate type, (c) succession relation type and (d) complement type.

\subsection{Modifier-predicate type [ $\left.v^{\prime} \mathrm{V}\left[\mathrm{V}_{\mathrm{M}^{-}} \mathrm{V}\right]\right]$}

It should be noted that, unlike Old Japanese, in which coordinate multi-verbs have the largest applicability of all complex predicates, the modifier-predicate type appears relatively productive in Early Middle Japanese. Typical examples would be (11) and (12):

$\begin{array}{lllllll}\text { (11) あるか } & \text { なきか } & \text { に } & \text { 消え入り } & \text { つ } & \text { もの } & \text { し } \\ \text { aruka } & \text { nakika } & \text { ni } & \text { kieiri } & \text { tsutsu } & \text { mono } & \text { shi } \\ \text { have } & \text { have-NEG } & \text { DAT } & \text { disappear-into } & \text { CONT } & \text { thing } & \text { REST } \\ \text { 給ふ } & \text { を } & \text { 御覽ずる } & & & & \\ \text { tamahu } & \text { o } & \text { goransuru ni } & & & & \\ \text { HON } & \text { ACC } & \text { HON } & \text { DAT } & & & \end{array}$

"Looking at (Kooi), who is dying."

$(\mathrm{GJM} \cdot$ Kiritsubo)

(12) 水 の 流れ も 心 ゆき、池 の 面 澄み渡り mizu no nagare mo kokoro yuki ike no men sumiwatari water NOM flow FOC heart go.INF lake GEN surface pellucid "Heart goes as the water's flowing, prellucidly."

(EGM. Vol. 36)

A salient property of (11) and (12) is that it involves two verbal forms: a main verb, denoted by V2, i.e., 入る iri “come in”, 渡る wataru “cross", and an adverbial verb denoted by V1, i.e., 消える kie “disappear”, 澄むs sumu “to be pellucid”. All the constituents are intransitive.

\footnotetext{
${ }^{5}$ The reason why this paper refers to multi-verb construction as verb compounds will be explained shortly.
} 
There is another pattern of modifier-predicate $\mathrm{V}-\mathrm{V}$, formed by a transitive $\mathrm{V}$ combined with an intransitive $\mathrm{V}$, as illustrated in (13):

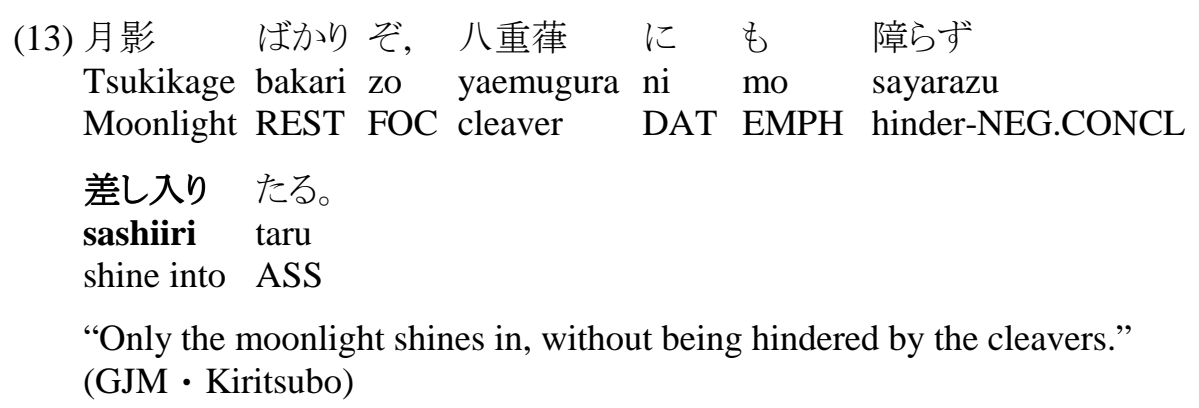

It should be noted at this point that it was not until Early Middle Japanese that the combination [V+iru] was allowed. ${ }^{6}$ Illustrations include omohi-iru "think over", kie-iru “disappear”, taei-ru 絶え入る, shini-iru 死に入る, nagame-iru 眺め入る, naki-iru 泣き 入る, and ne-iru 寝入る. In Old Japanese, such combinations are not allowed, as the combination of the two constituents seems quite loose. The reason, perhaps, has to do with the grammaticalization that iru has received in Early Middle Japanese, exhibiting a verb weakening. Though it may still indicate change of location, in most cases, the meaning has been metaphorized. In such constructions, the first constituent is the head and could bear either transitive or intransitive features. After Late Middle Japanese (a Japanese linguistic period spanning c. 1200-1600), osore-iru恐れ入る, yorokobi-iru 喜び入る appears, which further indicates that iru has become more dependent on the first constituent.

\subsection{Verb weakening}

The phenomenon of verb weakening is worth commenting on. Our data show the following words tend to appear in the preceding position in quite high frequency: 引く hiku “pull” (quadrigrade ${ }^{7}$ ), 押す osu “push" (quadrigrade), 掻 $<k a k u$ "scratch" (quadrigrade), 打つ utsu "hit" (quadrigrade).

The frequencies of these verbs appearing in the preceding position as well as the later position are the given in Table 2.

\footnotetext{
${ }^{6}$ There is a similar reference in Hyakutome (2001) regarding the auxiliarisation of the verb iru.

${ }^{7}$ Quadrigrade verb conjugation: a type of verb conjugation in classical Japanese.
} 
Table 2: Frequency of $u t s u$, etc. appearing in the preceding / later position

\begin{tabular}{|l|c|c|c|c|}
\hline Lexicon & $\begin{array}{c}\text { Preceding } \\
\text { position }\end{array}$ & $\begin{array}{c}\text { Later } \\
\text { position }\end{array}$ & Total & $\begin{array}{c}\text { Percentage of } \\
\text { preceding position }\end{array}$ \\
\hline \hline 押寸 osu "push" & 46 & 1 & 47 & $97 \%$ \\
\hline 打つ utsu "hit" & 67 & 8 & 75 & $89 \%$ \\
\hline 掻く kaku "scratch" & 35 & 1 & 36 & $97 \%$ \\
\hline 為 $s u$ “do" & 23 & 2 & 25 & $92 \%$ \\
\hline 引くhiku "pull" & 69 & 8 & 77 & $89 \%$ \\
\hline
\end{tabular}

As can be confirmed by citing the frequency from the database, hiku "pull", osu "push", kaku "scratch", utsu "hit" are likely to appear in the preceding position, which further indicates that their properties as action verbs are reduced and that these verbs appear to function like prefixes. It should be noted that when it comes to Modern Japanese, they are generally used as action verbs and bear strong agentivity.

At this stage, it would be appropriate to suggest these prefix-like verbs received "degrammaticalization" as the Japanese language developed.

It is also noticed that the following verbs are likely to appear in the later position: いだす idasu “exit” (quadrigrade), 付くtsuku "stick to" (quadrigrade), 騒ぐ sawagu “make a noise" (quadrigrade), ありく ariku “walk” (quadrigrade), 勝る masaru “surpass” (quadrigrade), 入る iru “in” (quadrigrade), 遣る yaru “give” (quadrigrade), 立つ tatsu "stand" (lower bigrade), 為す nasu “do" (quadrigrade), 寄る yoru "approach" (quadrigrade), いづ idu "exit" (quadrigrade), 果つ hatsu "realise" (quadrigrade), ゆく $\ u k u$ "push" (quadrigrade), 来 $k u$ "come” (ka-irregular), 来る kitaru “come” (quadrigrade), 得 $u$ “gain” (lower bigrade), 置 < oku “put" (quadrigrade), 渡る wataru “cross" (quadrigrade).

The frequencies of the above verbs appearing in the preceding or the later position are given in Table 3 .

Table 3: Frequency of idu etc. appearing in the preceding/later position

\begin{tabular}{|l|c|c|c|c||}
\hline Lexicon & $\begin{array}{c}\text { Preceding } \\
\text { position }\end{array}$ & $\begin{array}{c}\text { Later } \\
\text { position }\end{array}$ & Total & $\begin{array}{c}\text { Percentage of } \\
\text { Later position }\end{array}$ \\
\hline \hline いづ idu "exit" & 21 & 101 & 122 & $82 \%$ \\
\hline ありくariku "walk" & 2 & 45 & 47 & $95 \%$ \\
\hline 得 $u$ “gain" & 2 & 31 & 33 & $93 \%$ \\
\hline ゆくyuku “push" & 19 & 78 & 97 & $80 \%$ \\
\hline 来 $k u$ “come" & 18 & 77 & 95 & $81 \%$ \\
\hline 為すnasu “do" & 3 & 43 & 46 & $93 \%$ \\
\hline 渡る wataru "cross" & 9 & 78 & 87 & $89 \%$ \\
\hline
\end{tabular}




\begin{tabular}{|c|c|c|c|c|}
\hline Lexicon & $\begin{array}{c}\text { Preceding } \\
\text { position }\end{array}$ & $\begin{array}{c}\text { Later } \\
\text { position }\end{array}$ & Total & $\begin{array}{l}\text { Percentage of } \\
\text { Later position }\end{array}$ \\
\hline いだす idasu“exit" & 6 & 34 & 40 & $85 \%$ \\
\hline 寄る yoru “approach" & 6 & 45 & 51 & $88 \%$ \\
\hline 立つ tatsu "stand" & 15 & 51 & 66 & $77 \%$ \\
\hline 入る $i r u$ “in" & 15 & 76 & 91 & $83 \%$ \\
\hline 付 $<t s u k u$ "stick to" & 5 & 39 & 44 & $88 \%$ \\
\hline 置<oku "put" & 15 & 31 & 46 & $67 \%$ \\
\hline 果つ hatsu "realise" & 3 & 63 & 66 & $95 \%$ \\
\hline 勝る masaru “surpass” & 1 & 31 & 32 & $96 \%$ \\
\hline 来る kitaru "come" & 10 & 37 & 47 & $78 \%$ \\
\hline 遣る yaru “give" & 7 & 35 & 42 & $83 \%$ \\
\hline 騒ぐ sawagu “make a noise" & 3 & 19 & 22 & $86 \%$ \\
\hline
\end{tabular}

Table 3 indicates the following issue: verbs that are likely to appear in the later position are grammaticalized. Their meaning is metaphorized, i.e. either indicating a resultative state or spatial motion. In this regard, perhaps we can give the following rough subcategorization of verb weakening in Early Middle Japanese:

\section{(I) Verbs indicating motion:}

いづ idu "exit" (quadrigrade), ゆく yuku "push" (quadrigrade), 渡る wataru “cross" (quadrigrade), 来 $k u$ “come” (ka-irregular), ありく ariku “walk” (quadrigrade), いだす idasu "exit" (quadrigrade), 入る iru "in" (quadrigrade), 立つ tatsu "stand" (lower bigrade), 来る kitaru “come” (quadrigrade), 寄る yoru “approach” (quadrigrade)

\section{(II) Verbs indicating resultative state:}

遣る yaru “give" (quadrigrade), 果つ hatsu “realise" (quadrigrade), 付 $<t s u k u$ “stick to" (quadrigrade), 為す nasu “do" (quadrigrade), 勝る masaru "surpass" (quadrigrade), 得 $u$ “gain” (lower bigrade), 騒ぐ sawagu “make a noise" (quadrigrade)

Among the metaphorized meanings, verbs indicating motion occur more frequently than those that bear resultative state implications. This is possibly due to the fact that, during the Early Middle Japanese period, these verbs were partially grammaticalized. After Late Middle Japanese, iru became more dependent on the first constituent.

Bearing all this in mind, this paper postulates that verb weakening in Early Middle Japanese comprises two types, i.e. (a) transformation of the preceding verb into a prefix, (b) verbs whose meaning are transformed metaphorically and should be considered as directional/resultative complements. 


\subsection{Coordinate type [ $\left.{ }^{\prime}, \mathrm{V}[\mathrm{V}-\mathrm{V}]\right]$}

Having drawn a picture of the verb weakening, the following data present a further situation, where the coordinate type appears to be a common option for building a V-V in Early Middle Japanese.

$\begin{array}{lllll}\text { (14) 今日 明日 } & \text { 帰り去り なむ と } & \text { なるに } \\ \text { Kyo ashita } & \text { kaerisari } & \text { namu to } & \text { suru ni } \\ \text { Today tomorrow } & \text { return-leave } & \text { AUX COMP do DAT } \\ \text { "When he leaves and goes back (to his own country)" } \\ \text { (GJM. Kiritsubo) }\end{array}$

Note that in (14) the predicate is composed of two open-scale change morphemes, i.e. V1 kaeru "return" and V2 saru "leave". The two morphemes receive the same morphological and syntactic weighting.

\subsection{Succession relation type [ $v^{\prime} \mathrm{V}$ [V-V]]}

The following example is an illustration of succession V-V, whereby action or state denoted by V2 succeeds the one denoted by V1.

$\begin{array}{llllll}\text { (15) 年ごろ、 うれしく } & \text { 面だたし } & \text { き } & \text { ついでに } \\ \text { toshigoro } & \text { ureshiku } & \text { omodatashi } & \text { ki } & \text { tsuideni } \\ \text { age } & \text { happy.INF } & \text { honour. } & \text { ACOP.ADN } & \text { incidentally } \\ \text { て立ち寄り } & \text { 給ひ } & \text { し } & \text { もの } & \text { を... } & \\ \text { te tachiyori } & \text { tamahi } & \text { shi } & \text { mono } & \text { o } & \\ \text { come over. } & \text { HON } & \text { PAST } & \text { thing } & \text { ACC } & \end{array}$

"Please come over again at your convenience, for a rest."

$(\mathrm{GJM} \cdot$ Kiritsubo)

The two constituents are involved in a succession relation, and both of them, i.e. 立 tatu “stand" and 寄る yoru "approach", are independent motion verbs and equally contribute to the motion information.

\subsection{Complement relation type [ $v^{\prime} \mathrm{V}$ [V-C]}

There is another type of $\mathrm{V}-\mathrm{V}$, not as frequently used as the three patterns we have seen above, and is considered the least productive type in Early Middle Japanese, namely, the complement relation $\mathrm{V}-\mathrm{V}$, which contains the following different argument structures. 
Table 4: Different argument structures in Complement relation V-V

\begin{tabular}{|lc|l||}
\hline Argument structure & Example & V-V \\
\hline \hline 1. unergative V + unaccusativeV & $(16)$ & omoi-midareru \\
\hline 2. transitive V + transitive V & $(17)$ & hiroi-atsumeru \\
\hline
\end{tabular}

(16) 宮に に 逢う またとない機会源氏 Miya ni au matatonai kikai ni omoi midareru genji Court DAT meet precious opportunity DAT think-muddled Genji "Genji, who appears muddled when thinking it a precious opportunity to meet in the court."

(GJM·Wakamurasaki)

(17) かつて の 愛の 思い出を 拾い集めて

Matsute no ai no omoide o hiroiatsume te former GEN love COP memory ACC collect

むせび泣きました

musebi naki mashita

choke cry.PAST

"Thinking of the love once upon a time, could not help crying." (ISM)

\subsection{Interim recapitulation of the argument}

What the discussion so far demonstrates that morphosyntax has played the most significant role in Early Middle Japanese. The modifier-predicate type appears to have the largest applicability of all complex predicates and in this case it is the first constituent that is the head of the whole compound. Crucially, at this stage, a couple of verbs are grammaticalized and display verb weakening. In terms of the semantic constraints on argument structure, three ways of building V-V are possible, as listed in Table 5:

Table 5: Variation of argument structure of V-V in Early Middle Japanese

\begin{tabular}{|c|c|}
\hline Argument structure & Examples \\
\hline \multirow{2}{*}{ 1. transitive $\mathrm{V}+$ transitive $\mathrm{V}$} & a. hiki-agu "pull-ascend" \\
\hline & b. kikoshimeshi-iru "have someone in" \\
\hline \multirow{8}{*}{ 2. unaccusative $\mathrm{V}+$ unaccusative $\mathrm{V}$} & a. yuki-kaeru "go-return" \\
\hline & b. kaeri-idu "return-exit" \\
\hline & c. tachi-sofu "stand-escort" \\
\hline & d. tachi-hanaru "stand up-leave" \\
\hline & e. ide-afu "exit-meet" \\
\hline & f. uki-agaru "float-rise" \\
\hline & g. hahi-hairu "claw-enter" \\
\hline & h. yori-ku "approach-come" \\
\hline
\end{tabular}




\begin{tabular}{||l|l|}
\hline Argument structure & Examples \\
\hline \hline \multirow{3}{*}{ 3. transitive V + unaccusative V } & a. yuki-hanaru "go-leave" \\
\cline { 2 - 2 } & b. tazune-ku "come to visit" \\
\cline { 2 - 2 } & c. mi-kaeru "look back" \\
\hline
\end{tabular}

\section{The shift of V-V type from Old Japanese to Early Middle Japanese}

The development of the formation of verb compounds deserves thorough consideration. A closer look at multi-verb construction in Old Japanese (see (18)) reveals that the combination of the two constituents is rather loose. This might suffice to support the conclusion that in Old Japanese, the multiple verbs are assigned to an associate relation type rather than a compounding relation type.

\section{Examples of V-V combinations in Nara period}
(18) a. 出で行くide-yuku “exit-go"
b. 出で来 ide-ku “exit-come”
c. 鳴き渡る naki-wataru “cry-cross”
d. 濡れ通る nure-tooru "get wet-pass"
e. 乱れ出づ midare-idu “disrupt-exit”
f. 越え去ぬ koe-inu "cross-leave"
g. 越え行<koe-iku “cross-go"
h. 越え来 koe-ku “cross-come"
i. 立ち往ぬ tachi-inu “stand-leave"

If we compare an illustration drawn from the Kokin Wakash $\bar{u}$ (19a), an anthology of the waka form of Japanese poetry published in the Early Heian Period, with an illustration taken from the Tale of Genji (19b), a novel written in the Middle Heian period, we can see that the combination of the two motion verbs, i.e. sugu "pass" and yuku "go", appears quite loose and that their location can be reversed (see sugi-yuki vs. yuki-sugi).
（19）a. 神奈備 の山 山過ぎ行く秋なれば Kanabi no yama o sugiyuku aki nareba Kanabi GEN mountain ACC go by.CONC fall come-PROV "Fall, which has gone by the Kanabi Mountain." (KKW. Akishita)
b. 朝 ぼらけ 霧立つ空 の まよひにも
asa borake kiri tatsu sora no mayohi ni mo
morning break mist rise sky GEN haziness DAT FOC

$\begin{array}{lllll}\text { ゆき過ぎ } & \text { がたき } & \text { 妹 } & \text { が } & \text { 門かな } \\ \text { yukisugi } & \text { gata ki } & \text { imo } & \text { ga } & \text { kadokana } \\ \text { pass } & \text { hard } & \text { lady } & \text { NOM } & \text { door IJP }\end{array}$

"Even in the misty dawn, it is hard to pass the door of that lady." (GJM. Wakamurasaki) 
The free combination yields the claim that the two constituents receive equal morphological and syntactic weight. This leads us to deduce that multi-verbs in Old Japanese and Early Middle Japanese (Early Heian Period) probably exhibit a similar formation.

Bear in mind that combinations such as [V+入る iru] are not tolerated in Old Japanese, as iru is an independent motion verb entailing a spatial meaning. With regard to Middle Heian, the pattern of [V+入る iru] is extensively employed, as the following illustrations show:

\section{Examples of V-V combinations in Middle Heian period}

(20) [V+入る iru] (iru: partially grammaticalized)

a. 差し入り sashiiri “shine in"

b. 消え入り kieiri “vanish"

The original meaning of iru, indicating a spatial meaning, remains, but is weakened and the whole $\mathrm{V}-\mathrm{V}$ presents a metaphoric reading. V1 heads the whole compound and V2 conflates the path. Such V-V can be categorized as the complement relation type. Satellite framing is potentially suggested since the path is conveyed by an element other than the main verb. In Late Heian, iru has been fully grammaticalized and the following verb compounds result:

\section{Examples of V-V combinations in Late Heian period}

(21) $[\mathrm{V}+\lambda$ 万 iru $]$ (iru: fully grammaticalized)

a. 恐れ入る osore-iru "be obliged"

b. 喜び入る yorokobi-iru "pleased"

c. 思ひ入る omohi-iru "think over"

d. 絶え入る tae-iru "to expire"

e. 眺め入る nagame-iru "observe"

f. 泣き入る naki-iru "to burst into tears"

This directs our attention towards an assumption that it was not until the Middle Heian Period that verb compounds in the strict sense appeared. Accepting this, it seems appropriate to surmise that the development of writing systems might have lead to the shift of preference in the formation of the $\mathrm{V}-\mathrm{V}$ compounds.

\section{Conclusion}

This paper dealt with the formation of verb compounds in Early Middle Japanese based on a comparison of multi-verb constructions in Old Japanese. The findings strongly hint that it is the syntax/lexical semantics interface that mainly facilities the formation of multi-verbs in Old Japanese, whilst in Early Middle Japanese 
morphosyntax has a crucial role to play. Furthermore, compared with Old Japanese, verb compounds in Early Middle Japanese have come a long way. Multiple verbs in Old Japanese are assigned to an associate relation type rather than compounding relation type. Thus, the serial constituents receive equal syntactic weight, giving rise to the extensive use of the coordinate type and succession type of V-V combinations. In Early Middle Japanese, the combinations of the two constituents seem much tighter, resulting in the modifier-predicate type of $\mathrm{V}-\mathrm{V}$ compounds being employed most frequently. The conclusion that one can draw here is that it was not until Early Middle Japanese that verb compounds in strict sense appeared. Furthermore, in Early Middle Japanese, several verbs became grammaticalized and display verb weakening. Two variations of verb weakening have been observed: (a) verbs transformed into prefixes, (b) verbs whose meanings are metaphorized so that they can be considered directional/resultative complements.

\section{References}

Frellesvig, B. (2010). A History of the Japanese Language. Cambridge: Cambridge University Press.

Hyakutome, Y. (2001). Dooshi rensetsu kara fukugoodooshi e - iru no hojodooshika o chuushin ni. Bungei Kenkyuu. 152.

Li, W. (2012). Lexicalisation patterns in Japanese and Chinese: A synchronic and a diachronic perspective. Lincom Europa: Munich.

Li, W. (2011). A Comparison of Event Framing in Old Chinese and Old Japanese. Acta Linguistica Asiatica, 1(2), 57-72.

\section{Old Japanese data sources}

仏足石歌 Bussokuseki-ka (after AD. 753)

風土記歌謡 Fudoki kayō (AD.730)

古事記 Kojiki (AD. 712)

万葉集 Manyoshu (AD. 759)

日本書紀 Nihon shoki (AD.720)

The Oxford Corpus of Old Japanese: http://vsarpj.orinst.ox.ac.uk/corpus/

\section{Early Middle Japanese data sources}

\section{(a) Monogatari:}

栄花物語 Eiga Monogatari (AD. $11^{\text {th }}-12^{\text {th }}$ century)

源氏物語 Genji Monogatari (AD. Early $11^{\text {th }}$ century)

平家物語 Heike Monogatari (AD. $13^{\text {th }}$ century)

宇治拾遺物語 Ujishui Monogatari (AD. Early $13^{\text {th }}$ century) 


\section{(b) Nikki:}

土佐日記 Tosanikki (TSK)

枕草子 Makura no Sōshi (MKS)

\section{(c) Waka:}

古今和歌集 Kokin Wakashū (KKW)

\section{(d) Setsuwa:}

今昔物語 Konjaku Monogatarishū (KJM) 